\title{
The importance of intangible elements in the assessment of service quality in hotels in Kolubara District
}

\author{
Milan Vujić ${ }^{*}$, Dejan Sekulić ${ }^{2}$ Drago Cvijanović \\ ${ }^{1}$ Academy for Applied Studies Belgrade, The College of Hotel Management, Belgrade, \\ Serbia \\ ${ }^{2}$ University of Kragujevac, Faculty of Hotel Managament and Tourism in Vrnjačka Banja, \\ Serbia
}

\begin{abstract}
One of the hotel companies' key strategies in terms of increasing domestic and international competition is that the hotel service offer reflects a high quality level. Aim of this paper is to measure the guests' satisfaction level by the intangible components of offer in the Kolubara District hotels, i.e. to show the significance of this dimension in the total process of providing hotel services. Satisfied guests show a higher loyalty level, which represents a precondition for visiting the same hotel by the same guests and recommend it to their friends. The research was conducted in four hotels, where 100 respondents, the guests of the hotel, were surveyed. The research results showed that the intangible dimension of hotel offer can predetermine and increase the value of services to a large degree, and guests' satisfaction as the users of services as well.
\end{abstract}

Keywords: hotel industry, intangibility of services, quality of services, satisfaction JEL classification: M21, Z30

\section{Značaj neopipljivih elemenata u oceni kvaliteta usluge u hotelima u Kolubarskom okrugu}

Sažetak: Jedna od ključnih strategija hotelskih preduzeća u uslovima sve jače domaće i međunarodne konkurencije jeste da uslužna ponuda hotela odražava visok nivo kvaliteta. Cilj ovog rada jeste merenje nivoa zadovoljstva gostiju neopipljivim komponentama ponude u hotelima Kolubarskog okruga, odnosno da prikaže značaj ove dimenzije u ukupnom procesu pružanja hotelskih usluga. Zadovoljni gosti ispoljavaju veći stepen lojalnosti, što je preduslov da će gosti ponovo posetiti isti hotel i preporučiti ga svojim prijateljima. Istraživanje je sprovedeno u četiri hotela, pri čemu je anketirano 100 ispitanika koji su bili gosti hotela. Rezultati istraživanja su pokazali da neopipljiva dimenzija hotelske ponude u velikoj meri može predodrediti i povećati vrednost, a samim tim i zadovoljstvo gostiju kao korisnika usluga.

Ključne reči: hotelijerstvo, neopipljivost usluga, kvalitet usluga, satisfakcija JEL klasifikacija: M21, 330

*milan.vujic@vsar.edu.rs 


\section{Introduction}

The tangible and intangible elements of hotel service are very important in the hotel industry and tourism, because they play an important role in assessing the guests' satisfaction and the tourist's final decision in choosing a certain hotel or destination. Many satisfied users of the hotel services stay loyal, which means they will come back to a certain hotel or destination. Therefore, loyalty occurs as a consequence of the high quality of hotel service, in which the intangible component of service plays a key role (Vujić et al., 2018).

The intangible elements of hotel service refer to the totality of relations in the process of providing and using the hotel service program. Basically, this process is a way in which the hotel guest experiences and uses the service. The service process takes significantly more time than in other activities. At first, a potential guest gets various information on a hotel, communicates with the hotel, books accommodation and other services, comes to the hotel, stays at the hotel for a certain time, uses numerous services and then leaves the hotel. In this process of the service provision, human factor plays the dominant role in the guests' satisfaction level. According to Kotler and Bloom (1984) intangibility was defined as everything that cannot be seen, tasted, heard or smelled.

Employees are the most significant resource of a hotel company, and the quality of delivered services as well as the business success depends on their knowledge, skills, abilities and competencies (Perić et al., 2018). The hotel service provides in interaction between the employees and the service users. Guests, as well as the hotel service users and the hotel employees, realize a high communication and interaction level, which affects the quality of a hotel service product. In the hotel industry, the employees who make a direct contact with the guests are of the greatest importance for the quality of services, since they represent the key factor in satisfying guests and achieving their loyalty (Sekulić, 2017).

Satisfaction of the guests is based on the tangible (technical) and intangible (functional) dimensions of quality that are interdependent, but including differences as the result of experience and tradition in the service provision, expectations of the guests, the relation among hotel and guests, and the staff reliability. Technical quality refers to the guests' basic benefit obtained by the service (using room, food, and pool), and it is important in the evaluation of the service quality, while the functional quality refers to the process of creating and providing services and is related to the way in which the guest obtains, experiences and uses the service. At the same time, ensuring a consistent level of quality of the intangible service component represents the biggest problem in the hotel industry. These difficulties come out from a large number of interactions between the employees and guests. New situations, that both the guests and the employees experience subjectively, always emerge (conversation atmosphere, readiness to provide a service, kindness etc.). For example, one guest can prefer a bartender who speaks little, but is efficient and skilful, while some other guest may expect the same bartender to be a partner in conversation and get a lot of information from him (Barjaktarević, 2013).

The following hypotheses will be tested by this research.

H1: There is no statistically important difference in the respondents' attitudes regarding average grades of the hotel service components' intangible elements depending on the respondent's gender.

H2: There is a strong correlation between the intangible components of hotel service and the total satisfaction of guests during their stay in the hotel. 


\section{Intangible elements of the hotel service}

In modern business conditions, the hotel companies have to take care of the service quality, in order to be competitive on the market (Stanković, 2018; Šušić \& Đorđević, 2019). The significance of intangible dimension lies in the fact that it increases the service value and also the consumers' satisfaction. If the intangible service dimension is not in line with the service users' expectations, then a high level of material components cannot compensate dissatisfaction of users with the total hotel service.

The intangible dimension in the hotel industry is an unavoidable element in defining numerous terms, such as a hotel product, a service etc. British theorist Medlik (1980) pointed out five key components while explaining the hotel product. Those were: location, terms and the material character suit conveniences, services - style and manner of the service provision, price and image. Of everything above mentioned, the service is especially important for us, as the intangible component of the hotel product, whose content has been determined by terms and conveniences of material character, i.e. the material component that has determined potential for providing services, their scope, range and content. However, human factor, i.e. personnel employed in the hotel industry is the main characteristic of the style and way of providing services.

Dutch authors impose the so called PBE concept of the hotel product, and their approach distinguishes three groups of elements ( $\mathrm{P}$ - product, $\mathrm{B}$ - behaviour, and $\mathrm{E}$ - environment), which make the essence of the hotel product, if harmonically correlated. The group B, i.e. behaviour of the personnel means the intangible dimension in the hotel industry. This process implies direct communication between the personnel and guests, therefore these group elements refer to the quality of the service recipient - service provider relationship (Reuland et al., 1985).

If it is about the hotel service definition and its quality, they often comprise the tangible and intangible components. Thus, Kosar (2005) defined the hotel product quality as a market category that covers the occurrence of its tangible and intangible components by connecting them in an integral entirety. The hotel product quality was also defined as the realization of all related services ensuring that the processes comply with the requirements of hotel service. Čačić (2010) defined the hotel service as a set of tangible and intangible features provided to a guest, with an interpersonal relationship established with him/her, as well as his/her needs and expectations met, based on these features.

Numerous foreign authors describe the intangible elements of the hotel service through different assertions that can be classified in two groups. The first group consists of employees, i.e. their knowledge, skills, experience, understanding guests, friendly attitude toward guests, respect for guests, care, politeness, personal attention, tidiness etc. The second group represents the service process, which also affects: accuracy and efficiency in making a reservation, check-in speed, availability of a reserved room, accuracy in serving food in accordance with food ordered by a guest, correctness of all items in the bill, speed in the service provision, providing the service as promised, availability of information on the hotel services and their prices, solving problems, understanding guests' complaints (Akan, 1995; Akbaba, 2006; Dortyol et al., 2014; Juwaher, 2004; Oh, 1999).

The hotel industry today represents the global industry, which consists of the global consumers that use the hotel services worldwide (Čelić, 2019). The use of hotel contents, such as a room, a restaurant, a bar, a fitness centre and a pool, is not considered luxurious any more. For many users of hotel services, these contents are a component of their style (Sekulić \& Mandarić, 2013). Socio-psychological dimension of a working process in the hotel industry is based on staff, i.e. the employed personnel. The personnel ensure a special 
physiognomy and personality in functioning of the hotel industry. Individual work methods in hotels are present regardless of the achieved level of mechanization and automation of part of working process, and have a decisive effect on user's satisfaction by the hotel service. The personal character of hotel industry services implies the presence of users and direct communication with the employed personnel. Making contacts between employees and hotel guests makes an integral component of working process in the domain of basic and additional services (Kosar, 2008). Hotel employees represent the most important resource of every hotel, and the quality of delivered services depends on their competences. It is the employees who are the first link, someone guests meet first upon arrival at the hotel, and their performance affects the guest's perception of service quality. The hotel staff, as the intangible dimension in the hotel industry, has a key influence on the hotel service quality, which results in satisfied and loyal guests. Consumers' or hotel service userssatisfaction is the key for keeping and attracting new users (Urošević et al., 2018). The hotel's main goal, as any other company's, is satisfaction and value creation, which is especially significant for taking part on the market (Maričić, 2011).

\section{Research methodology}

The research was conducted in four hotels, where 100 respondents, the guests of the hotel, were surveyed. A survey questionnaire was created for collecting the primary data, and it was aimed at questioning the attitudes of the hotel guests. The questionnaire was distributed to respondents in printed form. Totally, one hundred questionnaires were filled out. The research was carried out in the period from September to November 2019, in the hotels located in the most important destinations of the Kolubara District, such as: Hotel Divčibare and Hotel Maljen in the mountain tourist destination Divčibare on Mount Maljen, Hotel Vrujci in Vrujci Spa, and Hotel Grand in Valjevo. The questionnaire consisted of three parts:

- The first part refers to the ascertainments, which reflect the guests' satisfaction with the quality of services during their stay at the hotel (26 questions);

- The second part covers questions, which refer to an overall opinion about staying at the hotel (4 questions);

- The third part of the questionnaire refers to the general type questions, which aimed to determine the demographic characterstics of the hotel guests.

The respondents expressed their attitudes on a seven-point Likert scale. The stated ascertainments were evaluated on a scale from 1 to 7 by the respondents, whereby 1 signified "the absolute dissatisfaction", while 7 signified "the absolute satisfaction". The data analysis was conducted by applying the statistical program IBM SPSS (Statistical Package for the Social Sciences SPSS 20). Within descriptive statistical analysis, there were calculated an arithmetic mean and a standard deviation for every ascertainment, in order to determine the ascertainments the respondents expressed the highest/the lowest degree of agreement with, as well as based on which ascertainments the respondents' attitudes were the most homogeneous/heterogeneous. Reliability analysis was used to determine a Cronbach's alpha coefficient for every variable in a model, which showed if the ascertainments, used for measuring the variables, were internally consistent. Statistically significant differences in the assessment of different socio-demografic characteristics respondents were determined by applying a t test. The correlation analysis was conducted in order to determine a degree of linear dependence between the observed variables. 
Vujić, M. et al. - The importance of intangible elements in the assessment of service quality in hotels in Kolubara District - Hotel and Tourism Management, 2020, Vol. 8, No. 2: 43-52.

\section{Research results}

The descriptive statistical analysis results are shown in Table 1. There were measured an arithmetic mean and a standard deviation for every individual ascertainment. More favourable attitudes of the respondents are present in those ascertainments with a higher value of arithmetic mean, while more homogenous atiitudes were present in the ascertainments with a lower value of standard deviation.

Table 1: The descriptive statistical analysis results - Kolubara District

\begin{tabular}{|c|c|c|c|}
\hline Variable & Ascertainment & M & SD \\
\hline \multicolumn{4}{|c|}{ During your stay at the hotel, how satisfied were you? } \\
\hline Hotel & Location of the hotel & 5.8750 & 1.20120 \\
\hline Hotel & $\begin{array}{l}\text { Visual appearance of the hotel (building, } \\
\text { lobby, reception desk) }\end{array}$ & 5.8208 & 1.21434 \\
\hline Staff & Tidiness of employees & 6.1099 & 0.95682 \\
\hline Staff & Kindness of employees & 6.1521 & 0.95891 \\
\hline Staff & Courtesy of employees & 6.1506 & 0.96151 \\
\hline Reception desk & Check-in and check-out speed & 6.0602 & 0.95888 \\
\hline Reception desk & Booking accuracy & 6.1401 & 0.95918 \\
\hline Reception desk & Availability of a reserved/allocated room & 6.0316 & 1.01448 \\
\hline Room & Cleanliness of a room while entering & 6.1476 & 0.97598 \\
\hline Room & Appearance and design of a room & 5.8720 & 1.10948 \\
\hline Room & Quality of furniture and equipment in a room & 5.8614 & 1.10617 \\
\hline Room & Bedcomfort (pillow, mattress, bed sheets, ...) & 5.8825 & 1.10725 \\
\hline Room & Room comfort & 5.8991 & 1.06942 \\
\hline Room & $\begin{array}{l}\text { Room equipment (mini bar,phone, } \mathrm{TV} \text {, } \\
\text { internet, coffee and tea maker) }\end{array}$ & 5.8840 & 1.15344 \\
\hline Hotel & The internet speed & 5.7545 & 1.19891 \\
\hline Room & Bathroom cleanliness & 6.0572 & 1.07895 \\
\hline Room & $\begin{array}{l}\text { Bathroom equipment (soap, shampoo, bath, } \\
\text { hairdryer) }\end{array}$ & 6.0090 & 1.03916 \\
\hline Room & $\begin{array}{l}\text { Appliances working properly (light, TV, air } \\
\text { conditioning) }\end{array}$ & 6.0633 & 0.98659 \\
\hline Hotel & Cleanliness of the hotel during the stay & 6.1310 & 0.92363 \\
\hline Restaurant and bar & Visual appearance of the restaurant and bar & 5.9488 & 1.07225 \\
\hline Restaurant and bar & Cleanliness of the restaurant and bar & 6.0904 & 0.95808 \\
\hline Restaurant and bar & Selection of food and beverages & 5.9910 & 1.05071 \\
\hline Restaurant and bar & $\begin{array}{l}\text { Food and drink quality (appearance, taste and } \\
\text { freshness) }\end{array}$ & 6.0000 & 1.06075 \\
\hline Hotel contents & $\begin{array}{l}\text { Equipment and appearance of the conference } \\
\text { and congress hall }\end{array}$ & 5.7590 & 1.26530 \\
\hline Hotel contents & Spa centres contents (pool, sauna, etc.) & 5.2519 & 1.85865 \\
\hline Hotel contents & $\begin{array}{l}\text { Other hotel contents (1. Parking, 2. Stores, } 3 . \\
\text { Children playground, 4. Recreational program) }\end{array}$ & 5.3614 & 1.66195 \\
\hline \multicolumn{4}{|c|}{ Your overall opinion about your stay at the hotel } \\
\hline Satisfaction & $\begin{array}{l}\text { In total, how satisfied are you with the quality } \\
\text { of service at this hotel in relation to the } \\
\text { expected service? }\end{array}$ & 5.8343 & 1.05489 \\
\hline Satisfaction & I have a positive opinion about the hotel & 5.7395 & 1.13754 \\
\hline
\end{tabular}


Vujić, M. et al. - The importance of intangible elements in the assessment of service quality in hotels in Kolubara District - Hotel and Tourism Management, 2020, Vol. 8, No. 2: 43-52.

\begin{tabular}{|l|l|c|c|}
\hline Satisfaction & I am ready to visit this hotel again in the future & 5.5753 & 1.24776 \\
\hline Satisfaction & $\begin{array}{l}\text { How satisfied are you with the total supply and } \\
\text { your expectation ratio? }\end{array}$ & 5.8298 & 1.07331 \\
\hline
\end{tabular}

$\mathrm{M}$ - Arithmetic Mean, SD - Standard Deviation

Source: Author's research

The ascertainments that refer to kindness, courtesy and tidiness of staff are classified in the variable Personnel. All ascertainments regarding check-in/check-out of guests (accuracy of reservation, avaliability of rooms, check-in/check-out speed) make the variable Reception Desk. Namely, the above mentioned ascertainments and variables represent the intangible component of the hotel service, by which we shall furthermore perceive the research results.

The descriptive statistical analysis results in table 1 show an average rating of the stated ascertianments given by the guests. The most favourable attitudes of the respondents were present regarding the ascertainments "During your stay in the hotel, how satsisfied were you with the kindness of the employees" and "......the helpfulness of the employees", where the arithmetic mean was the highest (6.15), then with "the accuracy of reservation" (6.14). All stated ascertainments belong exactly to the intangible elements of the hotel service. Besides the above mentioned, the other ascertainments that belong to this group have high average ratings. The most unfavourable attitudes of the respondents were regarding the ascertainment "During your stay in the hotel, how satsisfied were you with the SPA centre contents (pool, sauna etc.)", where the arithmetic mean had a lowest value of 5.25.

\subsection{Reliability analysis}

In such situation, when a particular variable is measured across several ascertainments, it is important to measure if that variable is reliable, i.e. if the ascertainments, by which the variable is measured, are consistent (Vujić et al., 2019). For the need of this analysis, a value of the Cronbach's alpha coefficient was calculated, ranging in the interval from 0 to 1 . The ascertainments were internally consistent, i.e. a variable was reliable if this coefficient value amounted to 0.7 and more. The reliabilty analysis results were shown in the Table 2, as well as the descriptive analysis results for formed variables.

Table 2: Reliability and desriptive analysis results for the formed variables - Kolubara

\begin{tabular}{|l|c|c|c|}
\multicolumn{5}{|c|}{ District } \\
\hline Variables & Cronbach's alpha & Arithmetic mean & Standard deviation \\
\hline Hotel & 0.793 & 5.9048 & 0.89544 \\
\hline Staff & $\mathbf{0 . 9 4 6}$ & $\mathbf{6 . 1 2 2 9}$ & $\mathbf{0 . 9 2 9 3 4}$ \\
\hline Reception desk & $\mathbf{0 . 8 9 5}$ & $\mathbf{6 . 0 9 6 6}$ & $\mathbf{0 . 8 9 6 7 1}$ \\
\hline Room & 0.957 & 5.9914 & 0.92604 \\
\hline Restaurant and bar & 0.924 & 5.9985 & 0.96291 \\
\hline Hotel contents & 0.838 & 5.3715 & 1.49897 \\
\hline Satisfaction & 0.895 & 5.8612 & 1.01666 \\
\hline
\end{tabular}

Source: Author's research

As it can be noticed in the Table 2, there is a high degree of internal consistency between the variables in a model.

According to the descriptive analysis results, it can be concluded that the hotel guests were mostly satisfied with the Personnel (arithmetic mean is the highest, 6.12), the Reception Desk activities (6.09), and the Restaurant and Bar work (5.99). On the other hand, the guests 
were the least satisfied with the available hotel Contents (playgrounds, parking, spa, etc.) the lowest arithmetic mean of 5.37.

Results in the Table 1 show that the ascertainments related to the intangible elements mostly have higher grades in regard to others. Furthermore, the descriptive analysis was determined that the variables Personnel and Reception Desk had better results of the arithmetic mean in regard to others. Those ascertainments and variables that were formed based on them, were belonging to a group of the most homogeneous attitudes.

\subsection{T test with two independent specimens}

The $t$ test was applied aimed to analyse the guests' attitudes depending on their gender. The $t$ test, with two independent samples, is used for comparison of two subsamples' attitudes (in this case, among male and female respondents). Statistically significant differences existed only if a level of test significance is lower than $0.05(\operatorname{sig}<0.05)$. In Table 3, the arithmetic mean and standard deviations for all formed variables are represented, differentiated by whether the hotel guests were male or female.

Table 3: Results of t test with two independent specimens: men and women

\begin{tabular}{|l|l|c|c|c|c|c|c|}
\hline \multirow{2}{*}{ Ordinal } & \multirow{2}{*}{ Ascertainment } & \multicolumn{2}{|c|}{ Men } & \multicolumn{2}{c|}{ Women } & \multirow{2}{*}{ t } & \multirow{2}{*}{ sig. } \\
\cline { 3 - 6 } & & $\mathbf{M}$ & SD & M & SD & & \\
\hline 1 & Hotel & 5.8921 & 0.91074 & 5.9258 & 0.87565 & -0.535 & 0.593 \\
\hline 2 & Staff & 6.1157 & 0.95183 & 6.1337 & 0.90011 & 0.276 & 0.783 \\
\hline 3 & Reception desk & 6.0578 & 0.89761 & 6.1462 & 0.89484 & -1.400 & 0.162 \\
\hline 4 & Room & 5.9744 & 0.90679 & 6.0258 & 0.92921 & -0.797 & 0.426 \\
\hline 5 & $\begin{array}{l}\text { Restaurant and } \\
\text { bar }\end{array}$ & 5.9806 & 0.94888 & 6.0221 & 0.98106 & -0.611 & 0.541 \\
\hline 6 & Satisfaction & 5.8162 & 1.02370 & 5.9184 & 1.00503 & -1.430 & 0.153 \\
\hline
\end{tabular}

Source: Author's research

As it can be noticed in the table, the female respondents were assessing every variable with a higher average grade than the respondents of male gender, except regarding the hotel personnel. It showed also a $t$ value that was negative for every variable. However, the statistically significant differences in the respondents' assessments on the basis of formed variables are present only if a sig value from the last column is lower than 0.05 . According to this adopted limit, it can be concluded that the statistically significant differences in the assessments of male and female respondents do not actually exist, therefore the hypothesis $\mathrm{H} 1$ is proven (There is no statistically significant difference in the respondents' attitudes related to the average grades of the intangible elements of hotel service components depending on the respondents' gender).

\subsection{Correlation analysis}

The correlation analysis shows a degree of dependence between two variables. In survey field researches a Pearson's coefficient value of the linear correlation is usually calculated, which shows a degree of linear dependence, i.e. a degree of quantitative match between the two variables. This coefficient value ranges from -1 to 1 . However, if the questionnaire contains positively scaled ascertainment (as is regarding our questionnaire, which contains the seven-point scales), this coefficient's value is positive and ranges from 0 to 1 . Thereby, the values from 0 to 0.4 point out to a weak linear correlation, from 0.4 to 0.6 to a moderate 
linear correlation, and from 0.6 to 1 to a strong linear correlation. Of course, it is important for the Pearson's coefficient value to be statistically significant at the level of 0.05 . Otherwise, the obtained value will not be statistically important and would not be considered. The correlation analysis results are presented in Table 4.

Table 4: The correlation analysis results

\begin{tabular}{|l|c|l|c|c|c|c|c|}
\hline & Hotel & Staff & $\begin{array}{l}\text { Reception } \\
\text { desk }\end{array}$ & Room & Restaurant & $\begin{array}{l}\text { Hotel } \\
\text { contents }\end{array}$ & Satisfaction \\
\hline Hotel & $/$ & $0.736^{*}$ & $0.731^{*}$ & $0.819^{*}$ & $0.793^{*}$ & $0.585^{*}$ & $0.748^{*}$ \\
\hline Staff & $0.736^{*}$ & $/$ & $0.767^{*}$ & $0.655^{*}$ & $0.719^{*}$ & $0.505^{*}$ & $0.752^{*}$ \\
\hline Reception desk & $0.731^{*}$ & $0.767^{*}$ & $/$ & $0.697^{*}$ & $0.690^{*}$ & $0.499^{*}$ & $0.694^{*}$ \\
\hline Room & $0.819^{*}$ & $0.655^{*}$ & $0.697^{*}$ & $/$ & $0.770^{*}$ & $0.492^{*}$ & $0.719^{*}$ \\
\hline Restaurant & $0.793^{*}$ & $0.719^{*}$ & $0.690^{*}$ & $0.770^{*}$ & $/$ & $0.630^{*}$ & $0.780^{*}$ \\
\hline Hotel contents & $0.585^{*}$ & $0.505^{*}$ & $0.499^{*}$ & $0.492^{*}$ & $0.630^{*}$ & $/$ & $0.609^{*}$ \\
\hline Satisfaction & $0.748^{*}$ & $0.752^{*}$ & $0.694^{*}$ & $0.719^{*}$ & $0.780^{*}$ & $0.609^{*}$ & $/$ \\
\hline
\end{tabular}

* - the value is statistically significant at the level of 0.001

Source: Author's research

As it can be noticed in the previous table, the linear correlation coefficients are statistically significant at the level of 0.01 . The highest degree of the linear correlation is present between hotel and room, with the Pearson's coefficient amounting 0.819, and it is about the strong linear correlation.

In the matrix, the moderate linear correlations can also be seen (for example Hotel Contents and Reception Desk), while there are no weak correlations between the tested variables. One of the highest degrees of the linear correlation is present in Personnel - Reception Desk, with the Pearson's coefficient 0.767 .

The correlation analysis determined the strong correlation between the intangible components of hotel services (Personnel and Reception Desk) and the total satisfaction of guests during their stay at the hotel. The Pearson's coefficient of linear correlation between the personnel and satisfaction amounts to 0.752 , while it amounts to 0.694 between the reception desk and satisfaction. In both cases there is a strong correlation, therefore the hypothesis $\mathrm{H} 2$ is confirmed (There is a strong correlation between the intangible components of hotel services and the total satisfaction of guests during their stay in the hotel).

\section{Conclusion}

Tertiary character defines the hotel industry as a labour-intensive activity, which implies a large share of the so-called current labour. Although numerous innovations of technicaltechnological character, especially computerization of business, are increasingly used in hotels, they do not diminish the significance of staff and their influence on shaping the final working form of the entire process in the hotel industry. Subjective assessment of service users, as an important factor of service quality in hotels, is predetermined to a large degree by the personnel operations, which represent the intangible elements of hotel service. Dual significance of the intangible elements in the hotel service quality assessment can be perceived. First, these elements increase an overall service value, and secondly, if these elements are not adjusted to the guests' expectations, a high level of tangible service elements cannot compensate dissatisfaction of guests by an overall hotel service either. 
With the previous analyses support, we can conclude that the significance of intangible elements in satisfying the service users, while assessing an overall hotel service, was proven. The empirical research results showed that the guests gave the highest grades to the intangible dimension in the hotel industry, which were presented here by the variables Personnel and Reception Desk. The female respondents evaluated all ascertainments with the highest average grades in comparison to the male respondents, except regarding the hotel staff. However, these differences are not statistically important. Finally, the impact of intangible elements on the total satisfaction of guests was tested by the correlation analysis. The correlation analysis results have confirmed the existence of a strong correlation between the service provided by the employees and the satisfaction of guests, as well as the reception desk activities and satisfaction. Further researches related to the intangible dimension improvement in the hotel industry are primarily a task of the hotel management, which should ensure the employees with greater job satisfaction through activities, such as: education and professional development, motivation and opportunity to progress, increase of life standard, improving interpersonal relationships, etc.

\section{References}

1. Akan, P. (1995). Dimensions of service quality: A study in Instabul. An International Journal, 5(3), 206-218. https://doi.org/10.1108/09604529510796575

2. Akbaba, A. (2006). Measurnig service quality in the hotel industry: A study in a business hotel in Turkey. International Journal of Hospitality Management, 25(2), 170192. https://doi.org/10.1016/j.ijhm.2005.08.006

3. Barjaktarević, D. (2013). Upravljanje kvalitetom u hotelijerstvu [Hotel quality management]. Belgrade, Serbia: Singidunum University.

4. Čačić, K. (2010). Poslovanje hotelskih preduzeća [Business of hotel companies]. Belgrade, Serbia: University Singidunum.

5. Čelić, I. (2019). The corporate social responsibility in Serbian hospitality industry. Economics of Sustainable Development, 3(2), 21-28. https://doi.org/10.5937/ESD1902021C

6. Dortyol, T., Varincli, I., \& Kitapci, O. (2014). How do international tourist perceive hotel quality? An exploratory study of service quality in Antalya tourism region. International Journal of Conteporary Hospitality Management, 26(3), 470-495. https://doi.org/10.1108/IJCHM-11-2012-0211

7. Juwaher, T. (2004). Exploring inernational tourist rercepctions of hotel operations by using a modified SERVQUAL approach - a case study of Mauritius. Managing Service Quality, 14(5), 350-364. https://doi.org/10.1108/09604520410557967

8. Kosar, Lj. (2008). Hotelijerstvo I [Hotel management I]. Belgrade, Serbia: The College of Hotel Managament.

9. Kosar, Lj. (2005). Defining quality in hotel industry [Definisanje kvaliteta u hotelijerstvu]. Researches Review of the Department of Geography, Tourism and Hotel Management, 33/34, 228-235.

10. Kotler, P., \& Bloom, P. (1984). Marketing professional services. Englewood Cliffs: Prentice Hall.

11. Maričić, B. (2011). Ponašanje potrošača [Consumer behavior]. Belgrade: CID; Ekonomski fakultet, Beograd.

12. Medlik, S. (1980). The business of hotels. London: Heinemann.

13. Oh, H. (1999). Service quality, customer satisfaction and customer value: A holistic perspective. International Journal of Hospitality Management, 18(1), 67-82. https://doi.org/10.1016/S0278-4319(98)00047-4 
14. Perić, G., Gašić, M., Stojiljković, M., \& Nešić, I. (2018). The impact of employee satisfaction on the tourist satisfaction with the services of spa tourism. Economics of Agriculture, 65(2), 617-632. https://doi.org/10.5937/ekopolj1802617p

15. Reuland, R., Choudry, J., \& Fagel, A. (1985). Research in the field of hospitality. Oxford: Pergamon.

16. Sekulić, D. (2017). Kvalitet u funkciji obezbeđivanja satisfakcije korisnika hotelijerskih usluga (Neobjavljena doktorska disertacija) [Quality in the function of ensuring the satisfaction of hotel service users (Unpublished Doctoral dissertation)]. Ekonomski fakultet, Univerzitet u Kragujevcu.

17. Sekulić, D., \& Mandarić, M. (2013). Quality of services as a determinant of customer satisfaction in the hotel industry. Marketing, 44(3), 231-246.

18. Stanković, M. (2018). The legal framework for tourism development in the Republic of Serbia. LAW - theory and practice, 35(1-3), 1-17. https://doi.org/10.5937/ptp1803001S

19. Šušić, V., \& Đorđević, D. Ž. (2019). Modern tendencies of international tourism development. Ekonomika, 65(2), 27-37. https://doi.org/10.5937/ekonomika1902027S

20. Urošević, S., Stanujkić, D., Karabašević, D., \& Brzaković, P. (2018). Using single valued neutrosophic set to select tourism development strategies in Eastern Serbia. Economics of Agriculture, 65(2), 555-568. https://doi.org/10.5937/ekopolj1802555u

21. Vujić, M., Anđelković D., \& Liberakos, A. (2018). Quality of hotel service as a factor of tourist destination. In S. Vićić (Ed.), Hotelplan 2018 Book of Proceedings (pp. 20-29). Belgrade, Serbia: The College of Hotel Management.

22. Vujić, M., Đorđević, S., \& Lakićević, M. (2019). Service quality and customer satisfaction in the hotel industry in Serbia. Menadžment u hotelijerstvu i turizmu - Hotel and Tourism Management, 7(1), 61-70. https://doi.org/10.5937/menhottur1901061V 